\title{
Características Isotópicas (N d e Sr), G eoquímicas e Petrográficas da Intrusão Alcalina do Morro de São João: Implicações G eodinâmicas e Sobre a Composição do Manto Sublitosférico
}

\author{
$\mathrm{Nd}$ and Sr Isotopic, Geochemical and Petrographic Characteristics of \\ the Morro de São João Alkaline Intrusion: G eodynamic Implications and \\ the Composition of the Sub-lithosperical Mantle
}

\author{
Carlos Eduardo Miranda Mota ${ }^{1}$ (mota@apterj.com.br), Mauro Cesar Geraldes² (geraldes@ uerj.br), \\ Julio Cesar Horta de Almeida² (jcha@uerj.br), Thaís Vargas² (thais@uerj.br), \\ Débora Marinho de Souza ${ }^{3}$ (deboramesmo@ hotmail.com), Renata de O liveira Loureiro ${ }^{3}$ (regeologia@ hotmail.com), \\ Aline Pimentel da Silva³ (aline.pimentel@oi.com.br) \\ ${ }^{1}$ Programa de Pós-graduação em Análise de Bacias e Faixas Móveis - Faculdade de Geologia - UERJ \\ R. São Francisco Xavier 524, CEP 20559-900, Rio de Janeiro, RJ, BR \\ ${ }^{2}$ Faculdade de G eologia - UERJ, Rio de Janeiro, RJ, BR \\ ${ }^{3} \mathrm{G}$ raduação da Faculdade de Geologia - UERJ, Rio de Janeiro, RJ, BR
}

Recebido em 12 de fevereiro de 2007; aceito em 22 de setembro de 2008

\begin{abstract}
RESUMO
O Complexo Alcalino do Morro de São João está localizado a NE do Estado do Rio de Janeiro e se destaca pelo desnível acentuado do relevo, sendo composto por dois tipos de rochas: sienitos félsicos de granulometria grossa (K-feldspato, nefelina, hornblenda e titanita, além de pseudoleucita) e melassienitos (com K-feldspato, anfibólio e piroxênio). Dados litogeoquímicos sugerem uma suíte bimodal e observações de campo indicam texturas de misturas de magmas e mingling locais, sugerindo que ambos foram contemporâneos. Os resultados isotópicos de $\mathrm{Nd}$ e $\mathrm{Sr}$ indicam valores próximos do EMI (Enriched Mantle I - Manto Enriquecido tipo I), sugerindo que a origem destas rochas ocorreu no manto sublitosférico a partir de um reservatório enriquecido com baixos valores ${ }^{87} \mathrm{Sr} /{ }^{86} \mathrm{Sr}$ (entre 0,7049 e 0,7061 ) e ${ }^{143} \mathrm{Nd} /{ }^{144} \mathrm{Nd}(\mathrm{entre}$ 0,512361 e 0,512428 ). Os valores de $\varepsilon_{\mathrm{Nd}}$ entre -4,03 e -5,54 indicam uma fonte mantélica anômala e enriquecida, o que é corroborado pelos valores de $\mathrm{T}_{\mathrm{DM}}$ entre 730 - $830 \mathrm{Ma}$, discordantes com idades de resfriamento K-Ar, que possuem valores entre 72 - $56 \mathrm{Ma}$. A comparação das assinaturas isotópicas de $\mathrm{Sr}$ e Nd das rochas do Morro de São João com ilhas vulcânicas (Trindade, Santa Helena e Tristão da Cunha) indicam que elas possuem similaridades com Tristão da Cunha e certa discrepância em relação às assinaturas de Trindade e Santa Helena.
\end{abstract}

Palavras-chave: Morro de São João, rochas alcalinas, geoquímica isotópica.

\section{ABSTRACT}

The Morro de São João Alkaline Complex (MSJ) is located in the NE part of Rio de Janeiro State and shows pronounced topography, with the following lithology: coarse-grained felsic syenites (K-feldspar, nepheline, hornblende, titanite and pseudoleucite), and mafic syenites (with K-feldspar, hornblende and piroxene). Petrography and lithogeochemistry data suggest a bimodal suite. Felsic and mafic magma mixing and mingling textures are locally observed indicating the presence of coeval magmas. Nd and Sr isotope compositions correspond to EMI (Enriched Mantle I) mantle reservoir signatures, suggesting an asthenospheric enriched mantle source with ${ }^{10}{ }^{87} \mathrm{Sr}{ }^{86} \mathrm{Sr}$ values (from 0.7049 to 0.7061 ) and low ${ }^{143} \mathrm{Nd} /{ }^{144} \mathrm{Nd}$ (from 0.512361 to 0.512428 ). The $\varepsilon_{\mathrm{Nd}}$ values range from -4.03 to -5.54 , indicating an anomalous enriched mantle reservoir, confirmed by the high $\mathrm{T}_{\mathrm{DM}}$ values between 730 - $830 \mathrm{Ma}$, very different from the 72 - $56 \mathrm{Ma} \mathrm{K}$-Ar cooling ages. The comparison of $\mathrm{Sr}$ and Nd signatures with related hotspot traces (Trindade, St. Helena and Tristan da Cunha) indicates that they are similar to those of Tristan da Cunha, but somewhat different from those of Trindade and St. Helena.

Keywords: Morro de São João, alkaline rocks, isotopic chemistry. 


\section{INTRODUÇÃO E OBJETIVOS}

O Complexo Alcalino do Morro de São João é uma intrusão localizada a nordeste do Estado do Rio de Janeiro, no município de Casimiro de Abreu. Este corpo formado no Cretáceo Superior (Amaral et al., 1967; Cordani e Teixeira, 1979; Sonoki e Garda, 1988) é intrusivo em rochas gnáissicas pré-cambrianas de composição granítica a granodiorítica pertencente à Unidade Região dos Lagos (Helmbold, 1967; Hasui, Carneiro e Coimbra, 1975; Heilbron et al., 2004; Schmitt et al., 2005). A gênese desta intrusão é interpretada, segundo a literatura, por uma reativação tectônica (Marsh, 1973; Alves, Sichel e Sperle, 1997; Oureiro et al., 2005), enquanto que outros autores apontam para uma gênese ligada a ação de uma pluma mantélica nessa região (Hertz, 1977; Thompson et al., 1998; Thomaz Filho e Rodrigues, 1998; Thomaz Filho et al., 2005).

A área de estudo está localizada na folha Morro de São João escala 1:50.000 (SF23-Z-B-VI-2) e seus arredores. O Morro de São João dista $8 \mathrm{~km}$ da cidade de Rio das Ostras RJ, e tem de 4 a 5 km de diâmetro e cota máxima de 806 m, sobre uma planície com cota de 20-25 m (Figuras 1 e 2).

A primeira referência à geologia da área em questão deve-se a Lamego (1956), que caracterizou os processos genéticos das rochas sedimentares observadas nas zonas de restinga entre Rio das Ostras e Barra de São João, entre esta cidade e a ponta dos Búzios, e das embocaduras dos rios das Ostras e São João. Oliveira (1952) cita o Morro de São João, denominando de Morro Grande de São João, atribuindo-lhe rochas de composição sienítico-nefelínicas. Citou ainda a presença de aluviões quaternários, "sedimentos Barreiras" e "zonas arqueanas" nos arredores.

Rosier (1965) apresenta dados esparsos de litologia, foliação do gnaisse e contorno do Morro de São João. Amaral et al. (1967) apresentam dados geocronológicos de duas amostras do Morro de São João, codificadas pelos autores de SPK-230 e SPK-304, com idades de 58,7 Ma para um malignito e 60 Ma para um nefelina sienito.

Segundo Almeida (1976 e 1986) e Riccomini (1991), na região sudeste, este magmatismo representado pelo Morro de São João faz parte da "Província Serra do Mar" ou Rift Brasileiro do Sudeste. São observadas, aproximadamente, 30 intrusões formando uma faixa desde a cidade de Poços de Caldas (MG) até a Ilha de Cabo Frio (RJ). A maioria destas intrusões é formada por rochas de composição sienítica e monzonítica e seus equivalentes subsaturados, com variações texturais desde plutônicas a vulcânicas.

O DRM/RJ, em convênio com o INPE, lançou em 1976 o mapa geológico do Estado do Rio de Janeiro em escala 1:400.000, baseado em imagens de satélite, delimitando o Morro de São João e colocando as rochas metamórficas encaixantes no chamado "Complexo do Litoral Fluminen- se". O texto explicativo da região do Morro de São João, elaborado por Antônio Pereira dos Reis (DRM/RJ, 1998) representa o mais completo estudo das rochas alcalinas na área, complementado por Valença (1975), com descrições petrográficas, geoquímicas e também algumas datações $\mathrm{K}-\mathrm{Ar}$, apresentando idades entre 72 e $56 \mathrm{Ma}$.

Dados isotópicos de $\mathrm{Sr}$ e $\mathrm{Nd}$ das rochas alcalinas do Morro de São João foram pela primeira vez apresentados por Brotzu et al. (2007). Os autores sugerem que as razões ${ }^{87} \mathrm{Sr} /{ }^{86} \mathrm{Sr}(0,7048$ a 0,7061$)$ e ${ }^{143} \mathrm{Nd} /{ }^{144} \mathrm{Nd}(0,51231$ a $0,51239)$ são semelhantes às assinaturas isotópicas dos complexos alcalinos do Sudeste do Brasil, o que pode significar fontes equivalentes para a formação destas rochas.

Este trabalho tem por objetivo apresentar os resultados de investigações realizadas nas rochas do Morro de São João com mapeamento preliminar, na escala 1:10.000 (Figura 3), de estudos petrográficos, geoquímicos e isotópicos. Estes resultados foram discutidos e comparados com os estudos anteriormente realizados e permitem um avanço no conhecimento da gênese das rochas alcalinas do sudeste do Brasil.

\section{GEOLOGIA DO MORRO DE SÃO JOÃO}

\section{Mapeamento}

O mapeamento permitiu delinear o contato entre a intrusão alcalina e depósitos de talus com matacões métricos, especialmente dentro das reentrâncias do relevo, que coalecem ao atingir a base da encosta, encobrindo o contato do corpo alcalino com a rocha encaixante, observado somente em um ponto na encosta SE. Em adição, a estruturação do relevo foi delineada a partir de imagens aéreas. O embasamento local é composto por ortognaisses Paleoproterozoicos onde afloram biotita-gnaisse e biotita-hornblenda-gnaisses. Ao norte do corpo alcalino, fora da área apresentada na Figura 3, nota-se um lineamento no embasamento com direção N-S e lineamentos com direção NE$\mathrm{SW}$, enquanto que a oeste do corpo, a direção de lineamento mais acentuada é E-W. Esses lineamentos ressaltam uma quebra em degraus na topografia da região, decrescendo para sul até a planície onde está posicionada a intrusão em estudo. No Morro de São João é possível observar lineamentos em imagens de satélite com direção preferencial E-W, porém esta estruturação não foi observada na escala de afloramento. O mapeamento na escala de detalhe (1:10.000) no interior do corpo alcalino permitiu a identificação de litotipos félsicos e máficos (Figura 4), porém a densidade de afloramentos estudados e a complexidade dos contatos bem como da distribuição dos litotipos não permitiu mapeá-los nesta escala de trabalho, em boa parte por falta de afloramentos in situ adequados. 


\section{Geologia}

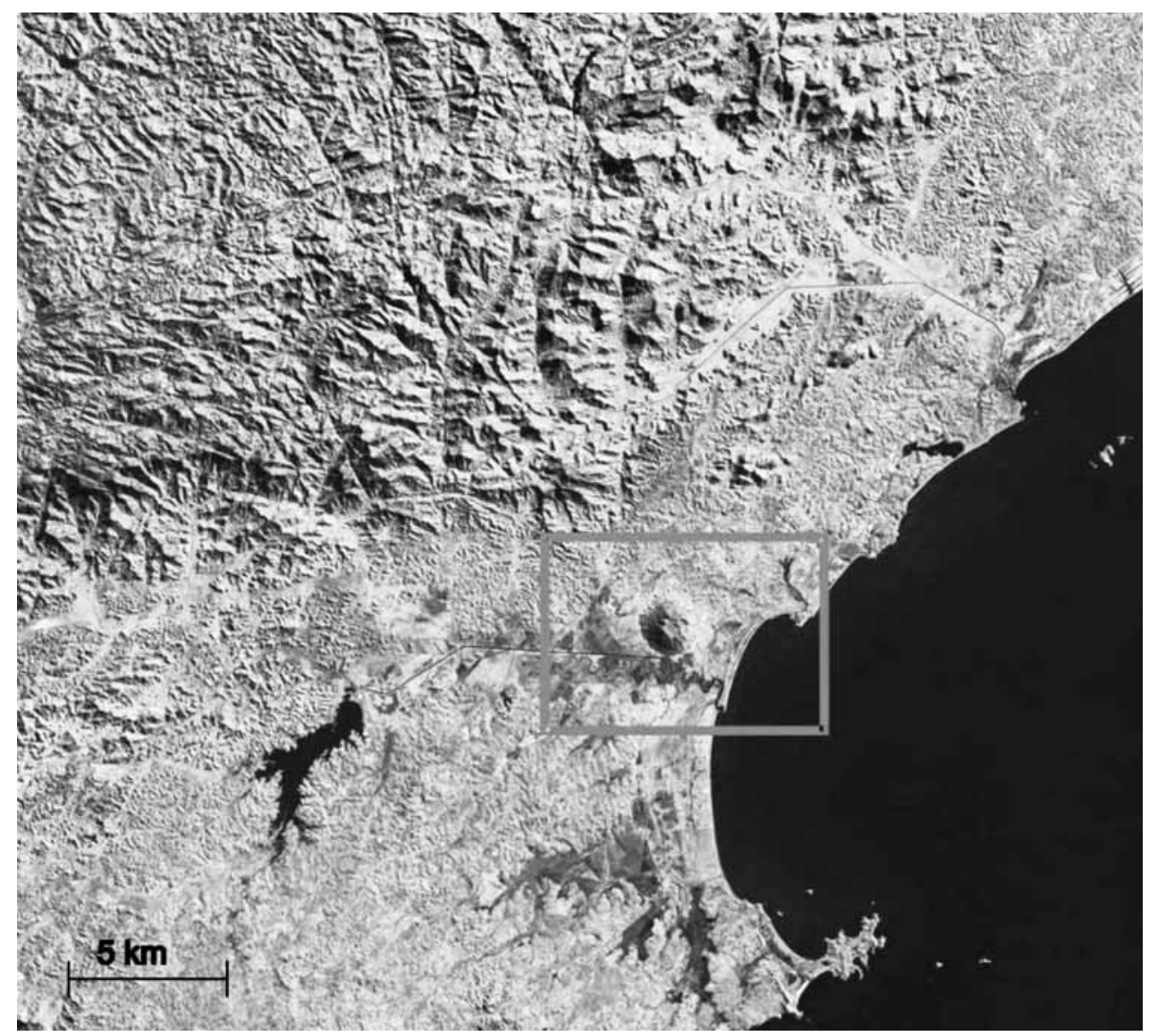

Figura 1. Imagem de satélite da região do Morro de São J oão.

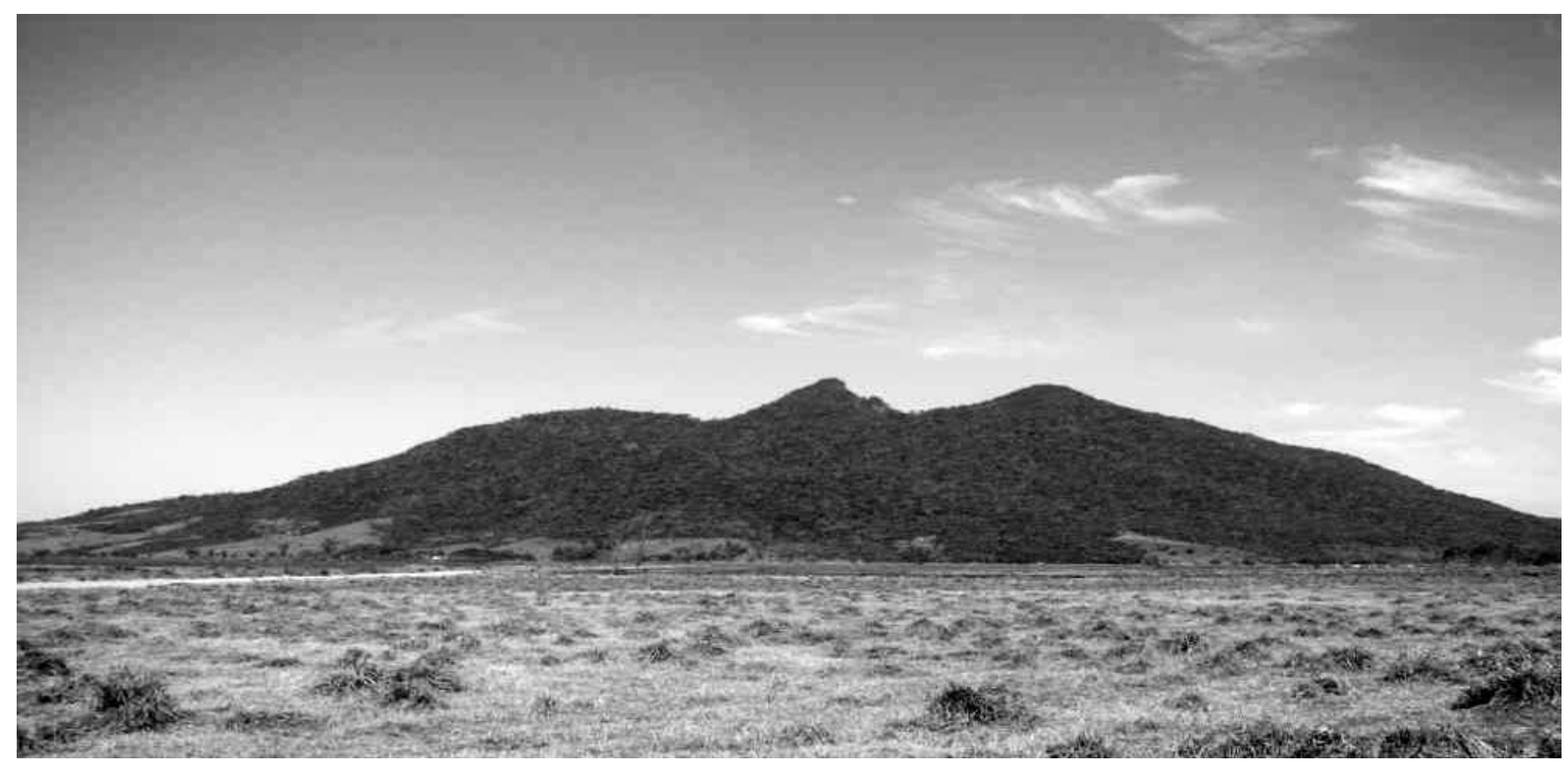

Figura 2. Visão geral do Morro de São J oão a partir de Rio das 0 stras. 0 pico mais alto atinge $806 \mathrm{~m}$. 


\section{Aspectos Petrográficos}

As rochas plutônicas predominantes do Morro de São João variam entre litotipos leucocráticos e melanocráticos. Os estudos petrográficos foram realizados com 20 lâminas delgadas e permitiram identificar também brechas magmáticas intrusivas de matriz leucossienítica, amplamente distribuídas no corpo. O grupo de rochas hipabissais está representado por corpos tabulares e por brechas magmáticas intrusivas de matriz fonolítica ou traquítica de ocorrência restrita à parte periférica do morro (Figura $5 \mathrm{~A}$ ). Neste sentido, os trabalhos de campo seguidos dos estudos petrográficos permitiram caracterizar as rochas do Morro de São João em dois grandes grupos definidos como (a) leucossienitos e (b) melassienitos.

Dois tipos de leucossienitos foram caracterizados nos estudos petrográficos. As rochas de granulometria grossa possuem, em geral, mineralogia definida por grãos de ortoclásio, na forma de ripas com geminação Carlsbad, em parte sericitizados (Figura 5B). A nefelina (Figura 5C) ocorre como grãos equidimensionais, prismáticos, xenomórficos, não orientados. Os minerais máficos (cerca de $10-20 \%$ do total da rocha) são representados por hornblendas idiomórficas e esverdeadas e pardas, juntamente com titanitas idiomórficas, losangulares, de coloração marrom-parda (Figura 5D). Piroxênios como a augita, egirina-augita e titanoaugita são de menor ocorrência. Pseudoleucitas equidimensionais entre 1 e $15 \mathrm{~cm}$ são comuns em algumas litofácies e também em proximidade com as rochas máficas.

O segundo grupo de rochas leucocráticas, hipabissais, ocorre na forma corpos tabulares de traquitos e fonolitos/ tinguaítos, cortando todos os outros tipos plutônicos (Figura 5B) e em certos locais são portadores de pseudoleucita. As rochas melanocráticas ocorrem em menor proporção em relação às leucocráticas, sendo encontradas distribuídas pelo maciço, também como brechas magmáticas envolvidas pelas rochas félsicas, em particular nas bordas do maciço, em contato com as rochas encaixantes. Possuem granulometria grossa com plagioclásio e anfibólio, com grãos medindo até $1 \mathrm{~cm}$, a maioria xenomórficos, porém alguns prismáticos.

Rochas indicando misturas entre magmas félsicos e máficos também são observados localmente, sugerindo que ambos os magmas foram contemporâneos. Nestes locais ocorrem passagens bruscas e gradacionais entre os litotipos leuco e melanocráticos. Fenocristais de feldspatos (ortoclásio) estão presentes na porção melanocrática, onde se concentram também pesudoleucitas. Em adição às fácies predominantes citadas, foram descritas as seguintes litologias neste corpo alcalino: álcali-feldspato sienitos (Figura 5E), nefelina monzossienitos, anfibólio malignitos, anfibólio shonkinitos, anfibólio fergusitos e pseudoleucita gabros (Figura 5F), que serão comentadas mais adiante.

\section{Leucossienitos}

Estas rochas afloram principalmente em forma de grandes blocos ao longo de toda a encosta do morro. No interior do maciço, porém, são muito comuns blocos de rocha fresca. Apresentam, em geral, granulação média a grossa, com índices de cor entre 5 e 25 (cinza-claro, com algumas variedades róseas). Os minerais máficos são distinguíveis a olho nu (anfibólios e/ou piroxênios, algumas titanitas e agregados de magnetita e ilmenita). Entre os leucossienitos são distinguíveis nefelina sienitos, micronefelina sienitos pórfiros, álcali-feldspato sienitos, pseudoleucita sienitos e nefelina monzossienitos.

Nefelina sienitos: estas rochas são constituídas por ortoclásio ripiforme e nefelina, representando a quase totalidade da composição mineralógica da rocha, enquanto que os minerais máficos, constituídos por piroxênios e anfibólios, são de ocorrência reduzida. Apresentam estrutura maciça e granulação grossa.

Os cristais ripiformes de ortoclásio, em seção delgada, apresentam-se límpidos, podendo aparecer turvos, e às vezes geminados segundo Carlsbad. É comum a presença de fenocristais de ortoclásio (textura porfirítica). A nefelina ocorre em grãos equidimensionais e prismas curtos, às vezes hexagonais tanto na matriz, como também em grãos maiores idiomórficos isolados. A nefelina pode ser encontrada também xenomórfica entre interstícios de grãos de ortoclásio. Ela também pode estar alterada para analcima, natrolita, e também pode aparecer às vezes com sodalita associada.

Os piroxênios são representados por cristais de augita e egirina-augita esverdeada, às vezes contendo núcleos de titanoaugita pálida. Os anfibólios, geralmente xenomórficos e em quantidade muito reduzida, são representados por barkevikita e hastingsita verde e parda.

Micronefelina sienitos pórfiros: estas rochas possuem granulação da matriz em torno de 0,05 a $0,25 \mathrm{~mm}$, formada por ripas de ortoclásio, nefelina e pequenos cristais de egirina-augita, com frequentes núcleos de titanoaugita. Os fenocristais são de ortoclásio apresentam granulometria entre 0,5 a $4 \mathrm{~mm}$. Observa-se ainda microcristais de nefelina, sodalita, analcita, magnetita, titanoaugita, titanita, magnetita, biotita, melanita e barkevikita.

Os cristais de ortoclásio se apresentam, em grande parte, homogêneos, em grãos retangulares, raramente geminados, constituindo agregados xenomórficos ou em cristais alongados idiomórficos, raramente pertíticos. Podem ser também encontrado, mais raramente, em ripas largas, com geminação Carlsbad. Geralmente os cristais são límpidos, podendo 
também ocorrer alguns cristais turvos e sericitizados. Em alguns exemplares, os cristais aparecem zonados.

A nefelina forma cristais idiomórficos ou xenomórficos em agregados, também encontrada em forma de grandes prismas hexagonais. É possível observar agregados xenomórficos equigranulares, juntamente com ortoclásio. A sodalita, às vezes pode aparecer associada à nefelina.

Os minerais máficos são representados por hastingsita e outras variedades de anfibólios, clinopiroxênios, biotitas, magnetitas, titanitas e melanitas. Os piroxênios são representados por augitas e titanoaugitas, frequentemente alterados para anfibólios, principalmente para hastingsita, ferrohastingsita e kaersutita, por vezes substituídos por agregados de biotita e melanita. Podem aparecer como alterações posteriores as zeólitas, carbonatos, muscovitas e zoisitas.

Álcali-feldspato sienitos: estas rochas são pouco frequentes e apresentam textura traquitoide, estrutura maciça e são compostos quase que exclusivamente de ortoclásio. Este mineral tem hábito ripiforme e por vezes apresenta-se em três tamanhos seriados, não orientados, com os grãos menores preenchendo os espaços entre os maiores. Encontram-se possíveis cristais de nefelina, totalmente transformadas em agregados finos, possivelmente compostos de feldspatos e zeólitas. Também podem ser observados alguns minerais máficos totalmente transformados em agregados finos de biotita, magnetita e carbonato.

Em um afloramento próximo da Pousada da Fazenda São João ocorrem blocos de sienitos com pseudoleucitas cortados por traquitos com granada. Estes traquitos são acinzentados com minerais submilimétricos como matriz e as granadas se destacam pelo tamanho e pelas cores avermelhadas. A granada pode ser descrita como melilita e segundo estudos composicionais neste mineral reportados por Brotzu et al. (2007) as composições são de baixo Ti (2,6 - 6,8 wt\%) e baixo Al (4,7 - 7,1 wt\%).

Cristais de biotita minúsculos são observados formados provavelmente a partir dos feldspatos. Esta alteração ocorre em agregados finos em espaços intergranulares, provavelmente em substituição à nefelina. Os minerais acessórios de cor amarela encontrados podem ser a allanita e a fluorita. Foram encontradas algumas vênulas de natrolita e nefelina.

Pseudoleucita-nefelina sienitos: estas rochas representam apenas uma variação dos nefelina sienitos contendo pseudoleucita. Por vezes são encontrados em grandes blocos nas encostas do morro e parecem ser muito frequentes. Apresentam estrutura maciça e textura hipidiomórfica granular.

O ortoclásio tende a exibir seção retangular, e se apresenta, por vezes, como grãos alongados xenomórficos e, junto com a nefelina equidimensional e inequigranular associadas à titanoaugita, esta frequentemente capeada por hastingsita verde e parda (ferro-hastingsita).
A pseudoleucita é muito comum em forma de zonas esféricas leucocráticas bem desenvolvidas (até $5 \mathrm{~cm}$ de diâmetro), com uma composição média de $72 \%$ de ortoclásio, $26 \%$ de nefelina, $1 \%$ de muscovita e $1 \%$ de carbonato. Às vezes apresenta bordas de feldspatos intercrescidos em paliçadas venulares róseas macroscópicas, contornando agregado granular de ortoclásio, nefelina e, raramente, muscovita, carbonato e máficos.

A matriz dessas rochas é de granulação muito variável, com grandes cristais de titanoaugita muito pleocroica, barkevikita, massa anedral de nefelina variavelmente alterada e massa mais fina de ortoclásio e nefelina. Segundo Brotzu et al. (2007) estas rochas teriam sido formadas por processos cumuláticos, onde o pseudoleucita sienito teria se formado numa fase inicial e posteriormente segregado, preservando a assembleia original.

Nefelina monzossienitos: estas rochas são pouco frequentes e ocorrem associadas aos nefelina sienitos. Apresentam estrutura maciça e textura hipidiomórfica granular. Dividem-se, segundo seus índices de cor, em a. nefelina monzossienitos, b. melanefelina monzossienitos e c. leuconefelina monzossienitos.

a. Nefelina monzossienitos: constituem-se de cristais idiomórficos de titanoaugita livres ou envoltos por grandes cristais poiquilíticos de barkevikita, por vezes passando a hastingsita verde. Apresentam uma massa leucocrática, formado por ortoclásio, alguns cristais poiquilíticos de nefelina e agregado de grãos de plagioclásio Às vezes, encontram-se nestas rochas pequenas massas dispersas, de composição gabroide (augita, biotita e labradorita), que são envolvidas e consumidas pela matriz leucocrática.

b. Melanefelina monzossienitos: estas rochas possuem estrutura maciça, por vezes levemente orientada. O ortoclásio, geralmente zonado, e a nefelina, rara e alterada, ocorre em cristais médios intersticiais, podendo esta última estar inclusa no ortoclásio. Os anfibólios são representados pela barkevikita (parda) e pela hastingsita (verde), ocorrendo em prismas poiquilíticos, com a hastingsita capeando a barkevikita, localmente cravejados de inclusões de outros componentes da rocha. A biotita pode aparecer associada à barkevikita, alem de titanita, a apatita e a melanita que aparecem como acessórios.

c. Leuconefelina monzossienitos: estas rochas apresentam na sua composição plagioclásio em forma de ripas agregadas ou como inclusões em ortoclásio. A nefelina aparece em grandes cristais equidimensionais. Anfibólio pardo com bordas esverdeadas pode estar presente em prismas grossos, por vezes associados a cristais idiomórficos de augita, englobando minerais acessórios em geral. 


\section{Melassienitos}

As rochas deste grupo são encontradas em blocos predominantemente em forma de brechas magmáticas intrusivas, de matriz sienítica. Possui índice de cor entre 30 e 80 , textura hipidiomórfica granular, granulação média a grossa, e cor predominante cinza-escuro. Distinguem-se a olho nu os minerais máficos e alguns feldspatos e nefelina. Entre os máficos, constata-se a presença de anfibólios e/ou piroxênios. Nota-se também, algumas titanitas e núcleos de magnetita e ilmenita. Estas rochas foram classificadas em malignitos, shonkinitos e anfibólio-fergusitos, apresentadas a seguir.

Malignitos: segundo a definição de malignito de Sфrensen (1974), estas rochas apresentam plagioclásio raro, em geral reabsorvido. São rochas sempre escuras e estrutura maciça. A mineralogia básica é praticamente a mesma dos nefelina sienitos, só que possuem índice de minerais máficos em torno de 50\%. Distinguem-se cristais de barkevikita, hastingsita e, subordinadamente biotita, arranjados numa matriz leucocrática de granulação média a grossa, formado por agregados de ortoclásio não geminado e nefelina. A nefelina possui hábito xenomórfico e os piroxênios mais comuns são: augita e titanoaugita, geralmente bordejados pelos anfibólios citados. A sodalita também está presente e com bastante frequência. São rochas relativamente comuns em blocos rolados nas encostas do morro.

Shonkinitos: são rochas de granulometria média a grossa. A textura é bastante variada (hipidiomórfica granular, poiquilítica e inequigranular) e a estrutura maciça. Encontram-se colunas piramidais ou placas de clinopiroxênio formadas por titano-augita e egirina-augita. Notam-se, por outro lado, grandes placas de biotita parda e barkevikita. Em adição observa-se nefelina intersticial, agregados de sanidina e produtos de alteração de nefelina (natrolita, sodalita e analcita). É comum a presença de grandes cristais intersticiais de nefelina alterados. Comumente observase titanoaugita e de titanita em cristais poiquilíticos muito grandes, que englobam os outros componentes da rocha. A biotita, assim como a barkevikita (parda), quando capeada de hastingsita (verde) aparece também em cristais poiquilíticos, incluindo apatita, magnetita, titanita e biotita parda substituindo titanoaugita.

Anfibólio fergusitos: seguindo a definição de fergusito, proposto por Johanssen (1939), mas de acordo com Streckeisen (1967), tais rochas deveriam ser denominadas de pseudoleucita malignito. Estas rochas apresentam estrutura maculada e textura hipidiomórfica granular. Distinguem-se grandes pseudoleucitas e os minerais máficos são representados por anfibólios e/ou piroxênios. A nefelina também pode ser observada em cristais amarelados. Nos anfibólio fergusitos do Morro de São João, a pseudoleu- cita se apresenta como esferoides brancos a acinzentados, às vezes rosados, consistindo essencialmente de agregados de ortoclásio, muscovita, nefelina alterada, um pouco de clorita, carbonato, zeólitas e produtos de alteração de titanaugita. A matriz básica é constituída de grandes cristais (1 - $5 \mathrm{~mm}$ ) de anfibólio, piroxênio e um fundo leucocrático formado por ortoclásio e nefelina. Este último mineral acha-se parcialmente transformado em sericita e cancrinita. $\mathrm{O}$ anfibólio é representado pela barkevikita que aparece em cristais com inclusões de titanita e núcleos de titanaugita. O piroxênio é a titanaugita que possui textura de desequilíbrio, com augita.

\section{Pseudoleucita gabros}

As rochas deste grupo têm estrutura maculada, textura hipidiomórfica granular e poiquilítica. Apresentam duas partes completamente diferentes em composição, uma constituída por esferoides de pseudoleucita e a outra, a matriz, de plagioclásio, titanaugita, titanita, magnetita, corpos saussuríticos, um pouco de biotita e hornblenda. A pseudoleucita se apresenta como esferoides brancos a acinzentados, às vezes rosados, consistindo essencialmente de agregados de ortoclásio sódico, muscovita, nefelina alterada, carbonato, zeólitas, alterações de titanoaugita e clorita, esta mais raramente. As formas de pseudoleucita mais arredondadas são compostas por um núcleo formado por um agregado fino (até $1 \mathrm{~mm}$ ) de ortoclásio, concentrações de muscovitas e zeólitas, o que pode representar a substituição total da nefelina. Alguns grãos de clinopioxênio semialterado em biotita e opacos podem estar presentes. Em adição, encontra-se uma coroa de material alterado, formado por feldspato algo fibroso, epidoto, muscovita e zeólitas. A matriz é constituída por grandes cristais, de até $5 \mathrm{~mm}$ de anfibólio, piroxênio e um fundo leucocrático formado por ortoclásio e nefelina, parcialmente transformado em sericita e cancrinita.

\section{Litogeoquímica}

No laboratório ACTLABS (Canadá), as técnicas analíticas empregadas incluíram ICP-AES para os elementos maiores. Os elementos traços $\mathrm{P}, \mathrm{S}, \mathrm{Cl}, \mathrm{Rb}, \mathrm{Sr}, \mathrm{Ba}$ e $\mathrm{Zr}$ foram analisados por fluorescência de raios-X, em pastilhas fundidas e espectrometria de absorção atômica foi utilizada para determinar $\mathrm{Mn}, \mathrm{Mg}, \mathrm{Na}, \mathrm{K}, \mathrm{Cu}, \mathrm{Mo}, \mathrm{Sn}$ e Pb. Espectrometria óptica para $\mathrm{Nb}, \mathrm{Y}, \mathrm{Ni}$ e $\mathrm{V}$. As terras raras foram analisadas por espectrometria de emissão com plasma induzido (ICP) e titulação com $\mathrm{KMnO}_{4}$ para $\mathrm{Fe}^{2+}$.

Os diagramas com resultados geoquímicos aqui apresentados (Tabela 1) são acrescidos dos dados geoquímicos reportados pelo DRM (1998) que permitem uma melhor delineação dos dois componentes magmáticos que 


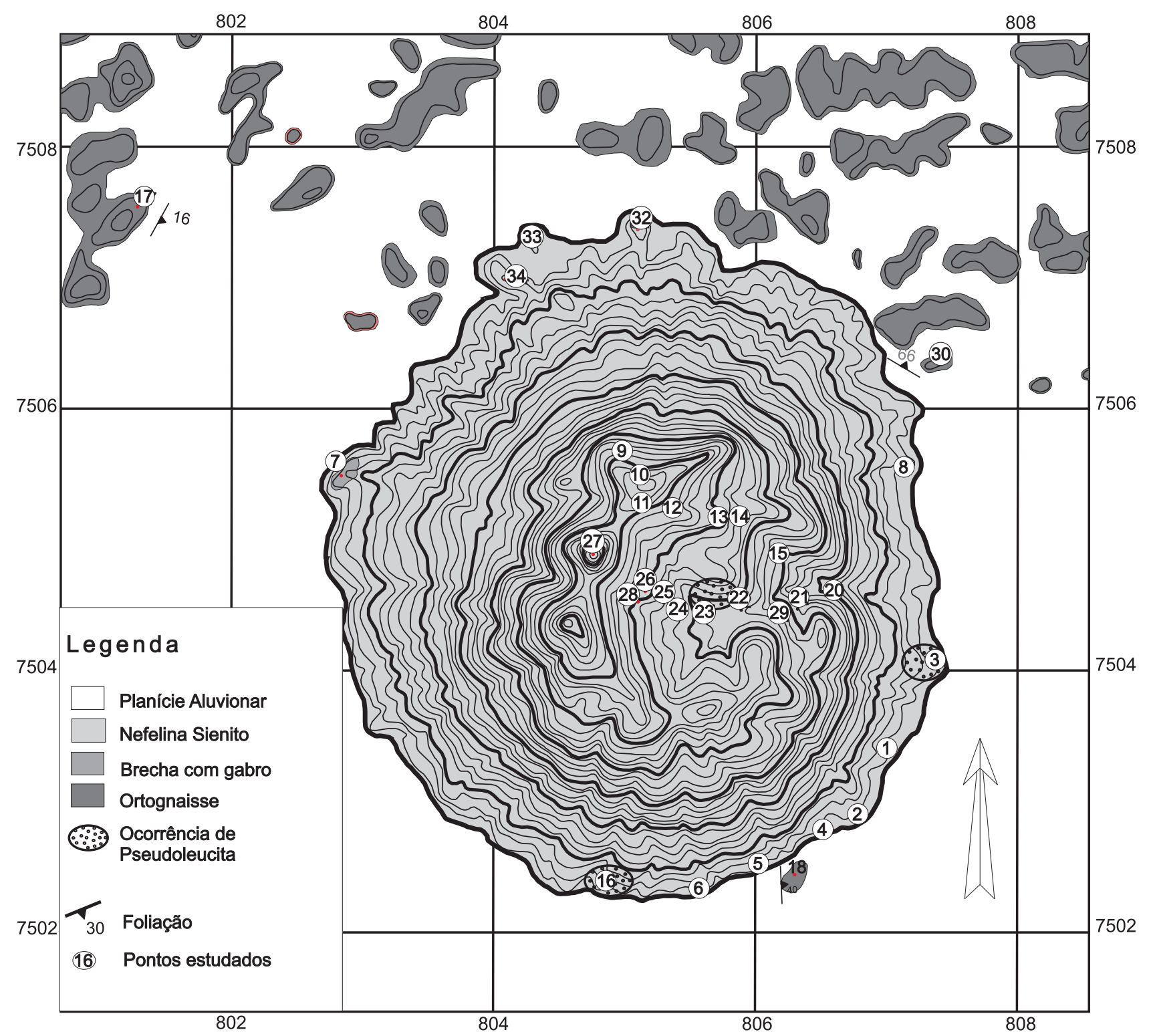

Figura 3. Mapa geológico simplificado com os pontos estudados do Morro de São J oão.

deram origem às rochas do Morro de São João. Vale ressaltar que os resultados geoquímicos de $\mathrm{TiO}_{2}$ e $\mathrm{Fe}_{2} \mathrm{O}_{3}$ apresentam valores com variações (entre os dados aqui reportados e os apresentados pelo DRM analisadas pela Geosol) provavelmente devido a diferenças de procedimentos analíticos. Estes diagramas ressaltam algumas características importantes: o padrão distinto de elementos maiores como o ferro, o magnésio e o cálcio, estes abundantes em rochas básicas (gabros), e com baixas concentrações nas rochas diferenciadas de composição sienítica. As análises geoquímicas de amostras do corpo alcalino do Morro de São João quando lançados em diagramas Harkers (Figura 6) indi- cam padrões lineares que podem ser interpretados como resultado de fracionamento magmático. Neste sentido, os óxidos $\mathrm{CaO}, \mathrm{MgO}$ e $\mathrm{Fe}_{2} \mathrm{O}_{3}$ (Figuras 6A a 6C) diminuem a quantidade com o aumento de $\mathrm{SiO}_{2}$. Este comportamento também é observado em relação aos óxidos $\mathrm{TiO}_{2}$ e $\mathrm{MnO}$ (Figuras 6D e 6E), porém com menor correlação com o $\mathrm{SiO}_{2}$. Em adição, o diagrama de $\mathrm{Na}_{2} \mathrm{O}$ vs. $\mathrm{SiO}_{2}$ apresenta correlação positiva, indicando o enriquecimento de sódio e sílica, correlação esta invertida no final do fracionamento magmático, quando ocorre a diminuição de $\mathrm{SiO}_{2}$ e mantido o enriquecimento de $\mathrm{Na}_{2} \mathrm{O}$ (Figura 6F) possivelmente como resultado da mudança da assembleia fracionante. 

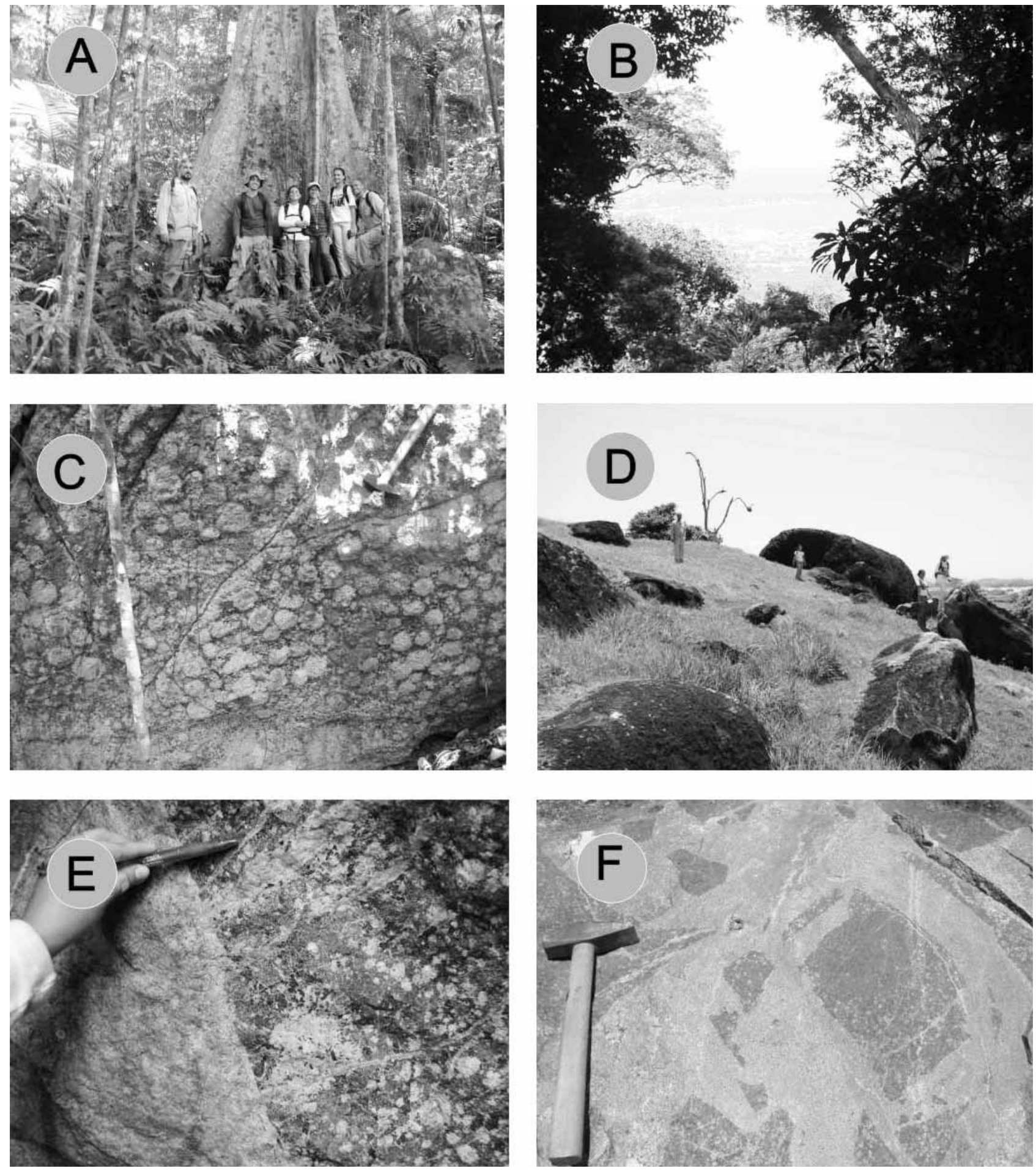

Figura 4. Fotografias das atividades de campo no Morro de São J oão. A. Densa vegetação do morro. B. Visão a partir do alto do morro. C. Pseudoleucitas. D. Afloramento no entorno do morro onde foi observado dique traquítico com granada. E. Conta to brusco entre as fácies félsica e máfica com pseudoleucitas. F. Brecha com matriz sienítica e fragmentos de gabro. 

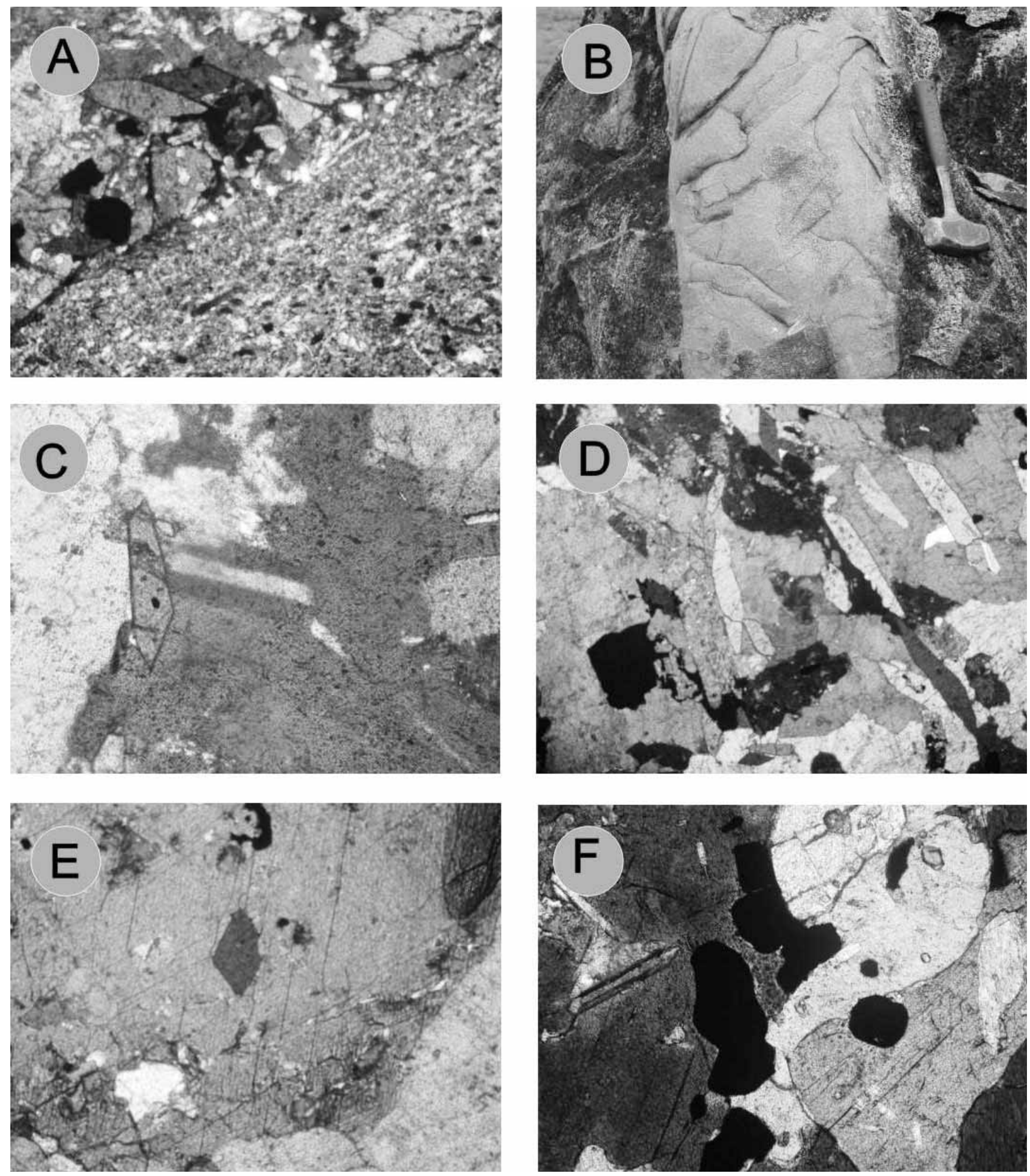

Figura 5. Fotografias das principais rochas observadas no Morro de São João. A. Contato em lâmina delgada entre gabro e traquito (nicóis cruzados). B. Afloramento de dique traquítico cortando sienito. C. N efelina sienito (nicóis descruzados). D. Gabro com titanita (cristais claros; nicóis cruzados). E. Fenocristal de feldspato alcalino em nefelina-sienito (nicóis cruzados). F. Plagioclásio (claros), opacos (magnetita) e mica (biotita) do gabro (nicóis cruzados). 


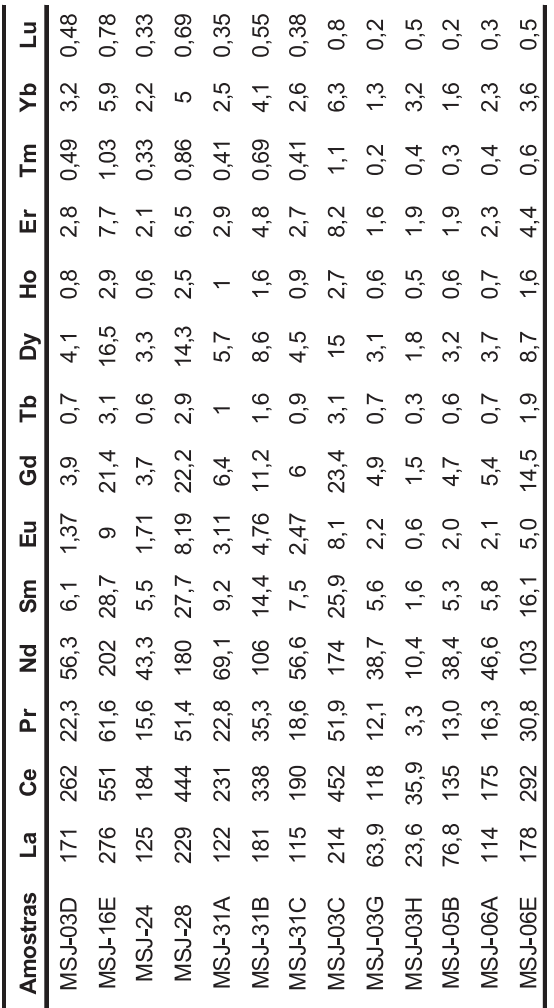

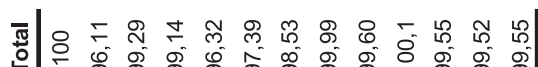

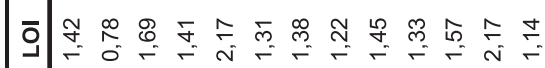

)

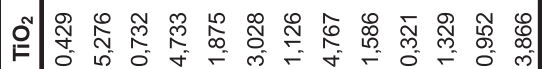

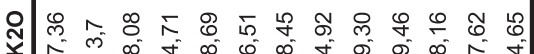

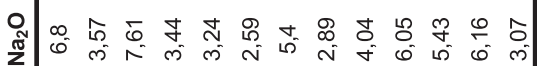

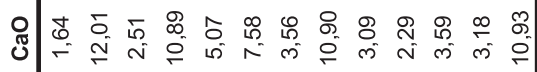

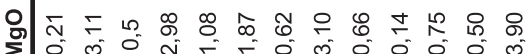

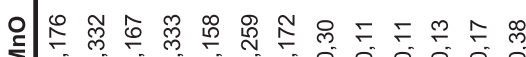

20000000

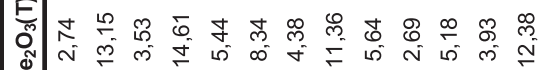

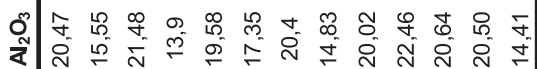

O

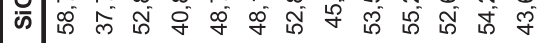

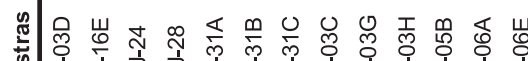

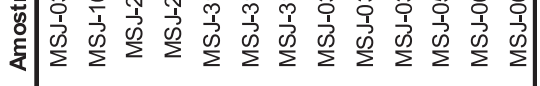

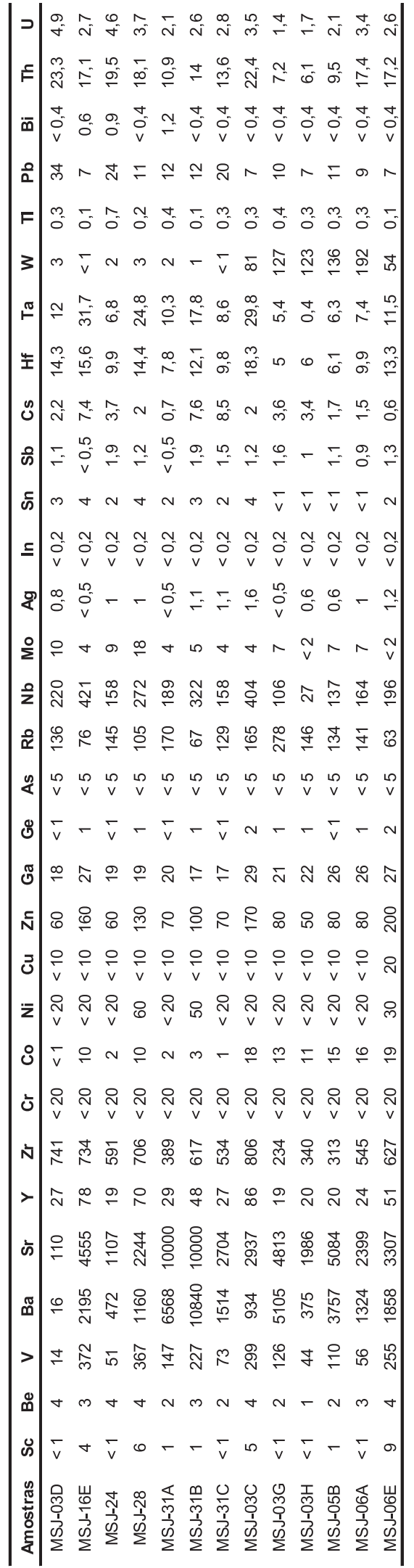



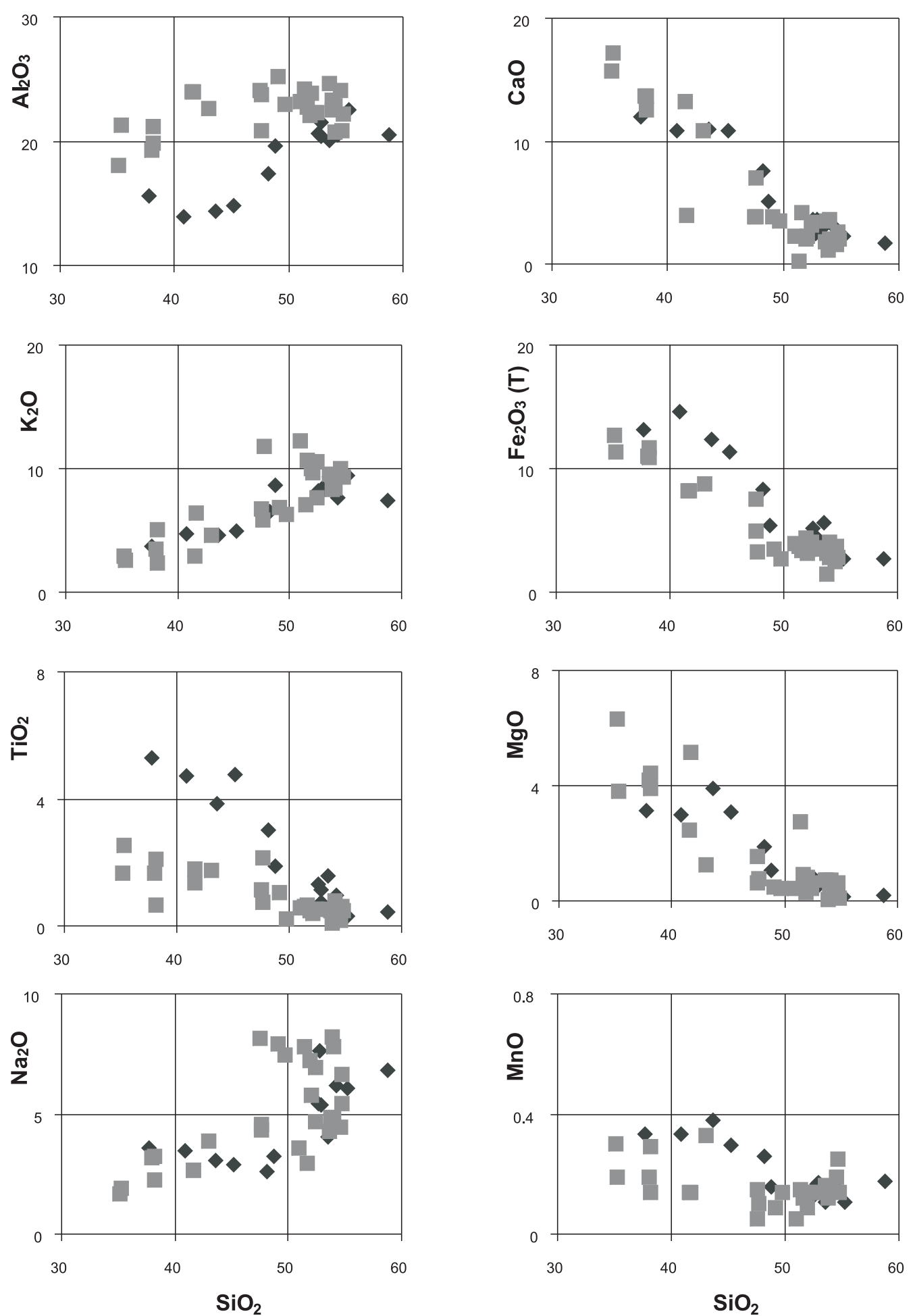

Figura 6. Diagramas Harkers de amostras de rocha do Morro de São João. Quadrados: dados do DRM-RJ. Balões: dados aqui reportados. 
Dados geoquímicos das rochas alcalinas do Morro de São João reportados por Brotzu et al. (2007) indicam fracionamento magmático como o processo gerador das rochas máficas a alcalinas, concordantemente com os resultados litogeoquímicos aqui reportados.

De acordo com a análise dos diagramas de elementos terras raras, observaram-se três diferentes padrões. As rochas máficas apresentam padrões mais horizontalizados (origem manto-derivada) (Figura 7). As rochas félsicas (Figura 8) apresentam padrão inclinado (provavelmente resultado de fracionamento magmático) sem anomalias negativas de Eu; o traquito rico em granada apresenta padrão inclinado invertido, com terras raras pesados em maior quantidade do que os terras raras intermediários, equivalentes aos padrões de ETR em granadas puras (Rollinson, 1993).

\section{Rochas máficas}

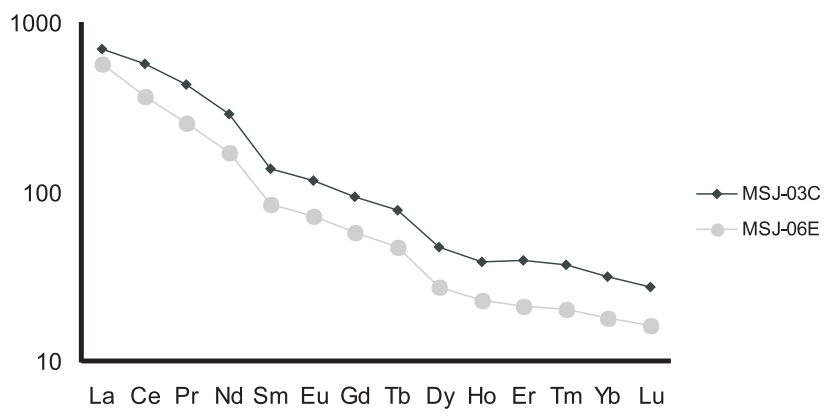

Figura 7. Diagrama de elementos terras raras em amostras de rochas máficas do Morro de São João. Os valores de terras raras foram normalizados segundo Sun e McDonough (1989).

\section{Rochas félsicas}

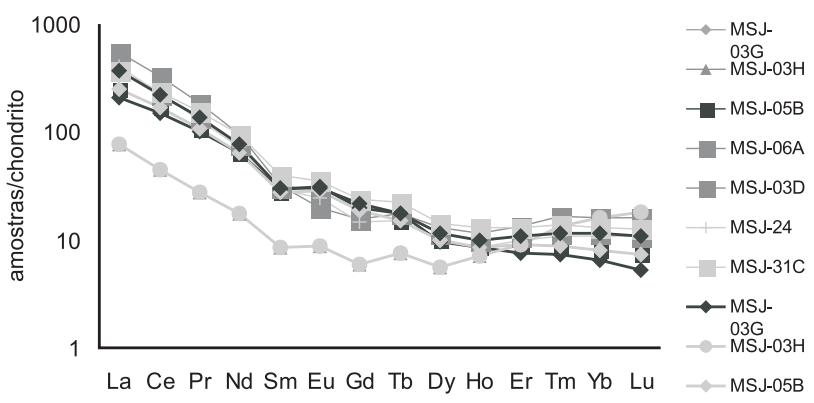

Figura 8. Diagrama de elementos terras raras em amostras de rochas félsicas do Morro de São João. Os valores de terras raras foram normalizados segundo Sun e McDonough (1989).
Os trabalhos de campo, adicionados dos estudos petrográficos e geoquímicos das rochas do Complexo Alcalino do Morro de São João, permitem sumarizar dois grupos litotipos principais: sienitos caracterizados pela sua composição com feldspato potássico, nefelina e anfibólio, e diques traquíticos, com ocorrência localizada de granada (melanita); e as rochas máficas com composição gabroica menos abundantes, mas indicativas da bimodalidade do magmatismo formador do Complexo Alcalino do Morro de São João. As distinções químicas entre as rochas máficas e félsicas, ressaltadas também nos padrões observados a partir da análise dos diagramas de elementos terras-raras, permitem sugerir uma origem mantélica para as rochas máficas e um processo de fracionamento magmático, a partir também de uma fonte mantélica, para a origem das rochas félsicas do Morro de São João.

\section{Isótopos de $\mathrm{Nd}$ e $\mathrm{Sr}$}

As amostras foram analisadas no laboratório de geocronologia isotópica do Instituto de Geociências da UNB. Para as análises de $\mathrm{Sm}-\mathrm{Nd}$ e $\mathrm{Rb}-\mathrm{Sr}$, foram utilizadas rochas pulverizadas, dissolvidas em $\mathrm{HF}$ e os traçadores ${ }^{145} \mathrm{Nd}$ e ${ }^{144} \mathrm{Sm}$ foram adicionados às soluções. No caso de $\mathrm{Rb}$-Sr não foram adicionados traçadores por se analisar a composição isotópica natural das amostras. A separação dos elementos terrasraras foi feita por colunas de troca catiônica com resina. As concentrações isotópicas destes elementos foram medidas no espectrômetro Finnigan, com multicoletores. Para os cálculos de razões isotópicas, do parâmetro $\varepsilon_{\mathrm{Nd}}$ e de idade modelo $\mathrm{T}_{\mathrm{DM}}$ foram utilizadas as seguintes constantes (De Paolo, 1988): ${ }^{146} \mathrm{Nd} /{ }^{144} \mathrm{Nd}=0,7219$ e $\lambda_{\mathrm{Sm}}=0,654 \times 10^{-11} \mathrm{ano}^{-1}$.

Os isótopos radiogênicos medidos a partir de amostras do Complexo Alcalino do Morro de São João foram utilizados para compreender os aspectos petrogenéticos visando à identificação de tipos de processos geológicos e composição (assinaturas isotópicas) de fontes, baseados em Zindler e Hart (1986). Os resultados isotópicos de $\mathrm{Nd}$ e $\mathrm{Sr}$ obtidos para as rochas do Morro de São João (Tabela 2) estão lançados no diagrama ${ }^{143} \mathrm{Nd} /{ }^{144} \mathrm{Nd} v s .{ }^{87} \mathrm{Sr} /{ }^{86} \mathrm{Sr}$ (Figura 9). Neste diagrama foram lançados também os dados isotópicos de $\mathrm{Nd}$ e $\mathrm{Sr}$ apresentados por Brotzu et al. (2007). O conjunto de resultados aqui obtidos e reportados na literatura indicam valores próximos ao reservatório EM I, sugerindo que a origem destas rochas ocorreu no manto sublitosférico a partir de um reservatório enriquecido com altos valores ${ }^{87} \mathrm{Sr} /{ }^{86} \mathrm{Sr}$ e baixos valores ${ }^{143} \mathrm{Nd} /{ }^{144} \mathrm{Nd}$.

Na Figura 10 é apresentado o diagrama de evolução isotópica de $\mathrm{Nd}$ incluindo os valores das amostras estudadas. Os valores de TDM entre 830 Ma e 730 Ma são discordantes das idades de cristalização ou resfriamento (por volta de 72-56 Ma; Amaral et al., 1967) sugerindo uma 
fonte mantélica enriquecida. Estas interpretações são coerentes com as interpretações do diagrama ${ }^{143} \mathrm{Nd} /{ }^{144} \mathrm{Nd} v s$. ${ }^{87} \mathrm{Sr} /{ }^{86} \mathrm{Sr}$ que reforçam a possibilidade de uma fonte mantélica enriquecida.

Datações radiométricas K-Ar realizadas em São Paulo (CPGEO-USP), para o DRM em 1976, foram publicadas por DRM-RJ (1998). As datações revelaram as seguintes idades para as rochas alcalinas do Morro de São João:

- Feldspato $=56,63 \pm 1,29$ Ma para um nefelina sienito.

- Anfibólio $=65,68 \pm$ 1,55 Ma para um melanefelina monzossienito.

- Biotita $=72,54 \pm 2,35$ Ma para um bytownita gabro.

Estas idades das rochas alcalinas do Morro de São João são concordantes com as idades obtidas nos outros corpos alcalinos entre $70 \mathrm{Ma}$ e $55 \mathrm{Ma}$, interpretadas como idades de resfriamento dos magmas alcalinos. A temperatura de fechamento do sistema K-Ar para anfibólio é ao redor de $500-550^{\circ} \mathrm{C}$, para a biotita é de $250-300^{\circ} \mathrm{C}$ e para o feldspato é de $150^{\circ} \mathrm{C}$. As idades mais velhas $(72,5 \mathrm{Ma})$ e mais novas (56,6 Ma) apresentam uma diferença de $14 \mathrm{Ma}$, demasiada longa para o resfriamento de um corpo intrusivo das dimensões do Morro de São João. Nesse sentido, podese conjecturar a hipótese de mais de uma intrusão ter participado na formação do corpo. Essa hipótese é corroborada com os dados reportados por Oureiro et al. (2005), no estudo de seções sísmicas dos sedimentos da Bacia de Campos. Neste estudo, os autores interpretam as rochas intrusivas nos sedimentos da plataforma continental como poli-intrusivas, com indicações de corte entre elas, sugerindo vários pulsos magmáticos sobrepostos na mesma área.

Tabela 2. Resultados isotópicos e N d e Sr das rochas do Morro de São João.

\begin{tabular}{|c|c|c|c|c|c|c|c|}
\hline Amostras & Sm (ppm) & $\mathrm{Nd}$ (ppm) & ${ }^{147} \mathrm{Sm} /{ }^{144} \mathrm{Nd}$ & $\begin{array}{c}{ }^{143} \mathrm{Nd} /{ }^{144} \mathrm{Nd} \\
\pm 2 \mathrm{SE}\end{array}$ & $\varepsilon_{(0)}$ & $\mathrm{T}_{\mathrm{DM}}(\mathrm{Ga})$ & $\begin{array}{c}{ }^{87} \mathrm{Sr} l^{86} \mathrm{Sr} \\
\pm 2 \mathrm{SE}\end{array}$ \\
\hline MSJ-06A & 7,59 & 54,83 & 0,0837 & $0,512377 \pm 4$ & $-5,09$ & 0,78 & $0,705144 \pm 1$ \\
\hline MSJ-03H & 2,36 & 16,54 & 0,0864 & $0,512354 \pm 20$ & $-5,54$ & 0,83 & $0,704991 \pm 2$ \\
\hline MSJ-06E & 18,8 & 125,2 & 0,0908 & $0,512424 \pm 17$ & $-4,16$ & 0,77 & $0,705346 \pm 4$ \\
\hline MSJ-03G & 6,28 & 44,53 & 0,0853 & $0,512414 \pm 10$ & $-4,03$ & 0,75 & $0,705068 \pm 1$ \\
\hline MSJ-03C & 28,93 & 199,47 & 0,0877 & $0,512361 \pm 23$ & $-5,41$ & 0,83 & $0,706095 \pm 6$ \\
\hline MSJ-05B & 6,22 & 44,58 & 0,0844 & $0,512428 \pm 19$ & $-4,09$ & 0,73 & $0,705031 \pm 3$ \\
\hline
\end{tabular}

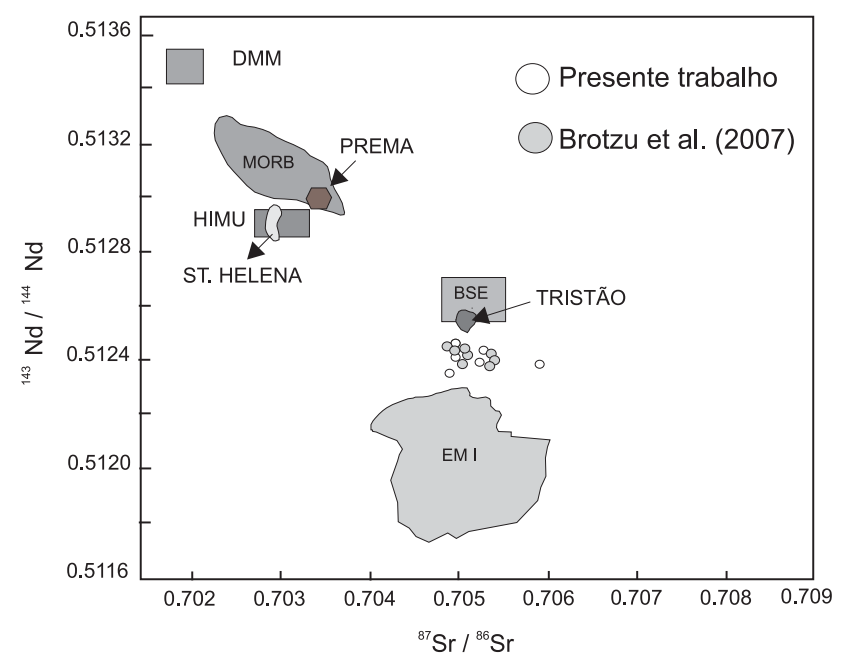

Figura 9. Diagrama ${ }^{143} \mathrm{Nd} /{ }^{144} \mathrm{Nd}$ vs. ${ }^{87} \mathrm{Sr} /{ }^{86} \mathrm{Sr}$ para as rochas do Morro de São João. Reservatórios mantélicos segundo Zindler e Hart (1986).

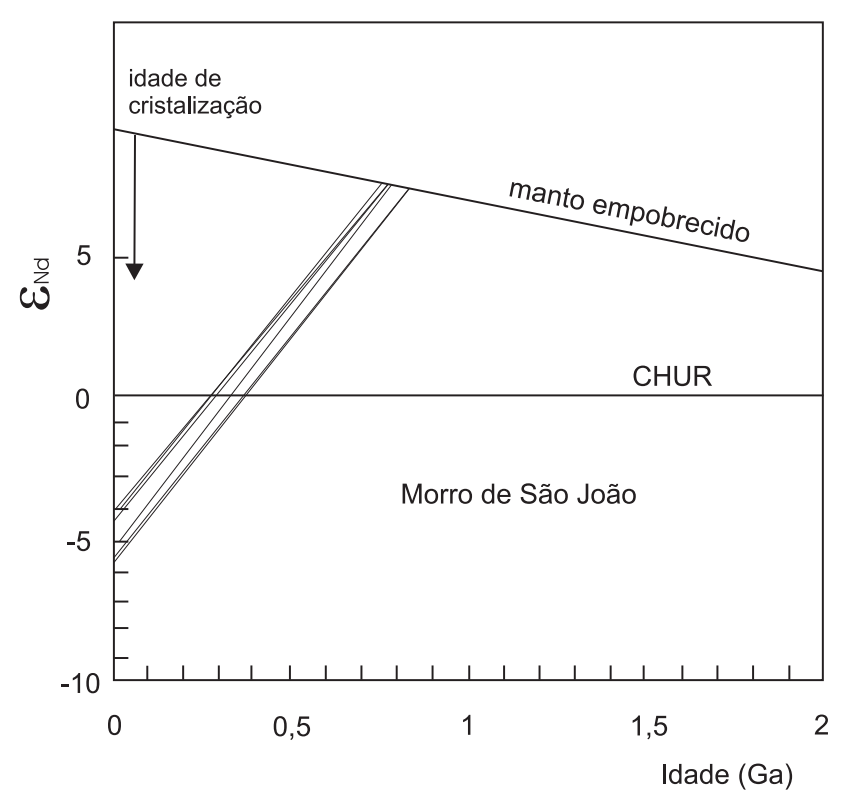

Figura 10. Diagrama de evolução isotópica de $\mathrm{N} d$ para as rochas do Morro de São João. 


\section{DISCUSSÃO E CONCLUSÕES}

O Morro de São João se destaca pela sua forma arredondada e pelo desnível acentuado de aproximadamente $800 \mathrm{~m}$, projetando-se em meio à planície, devido à erosão diferencial de rochas gnáissicas ortoderivadas que compreendem as encaixantes das rochas alcalinas. Esta intrusão não é controlada pela estruturação regional E/W, bem como seus congêneres, os corpos de Rio Bonito e Tanguá.

Dois tipos de rochas félsicas foram caracterizados quanto à composição mineralógica e textural. As rochas félsicas de granulometria grossa possuem mineralogia definida por feldspato potássico (ortoclásio), que se encontram em forma de ripas com geminação Carlsbard, alguns apresentam sericita como produto de alteração; e nefelina em grãos equidimensionais, prismáticos, xenomórficos, não orientados. Os minerais máficos definem cerca de $20 \%$ do total da rocha e são representados hornblendas idiomórficas e esverdeadas. Observou-se também titanita idiomórfica, com forma losangular, de coloração marrom-parda. Pseudoleucitas de tamanho entre 1 e $15 \mathrm{~cm}$ são comuns neste litotipo e também em proximidade com as rochas máficas. O segundo tipo de rocha félsica é representada por diques com textura porfirítica, constituídos fundamentalmente por uma massa fina de feldspato, nefelina e localmente granada.

As rochas máficas, por sua vez, ocorrem em menor proporção em relação às félsicas, sendo encontradas distribuídas pelo maciço, ou comumente na forma de brechas magmáticas envolvidas pelas rochas félsicas. Possuem granulometria grossa com feldspato potássico, plagioclásio e anfibólio, com grãos medindo até $1 \mathrm{~cm}$, a maioria xenomórficos, porém alguns prismáticos. Rochas indicando misturas entre magmas félsicos e máficos (mingling) também são observados localmente, sugerindo que ambos os magmas foram contemporâneos.

Os resultados isotópicos de Nd e Sr obtidos para as rochas do Morro de São João indicam valores próximo do reservatório EM I, sugerindo que a origem destas rochas ocorreu no manto sublitosférico resultado da fusão parcial de um reservatório enriquecido com altos valores ${ }^{87} \mathrm{Sr} /{ }^{86} \mathrm{Sr}$ (entre 0,7049 e 0,7061 ) baixos valores ${ }^{143} \mathrm{Nd} /{ }^{144} \mathrm{Nd}$ (entre 0,512361 e 0,512428$)$. Os valores de $\varepsilon_{\mathrm{Nd}}$ entre $-4,03$ e -5,54 indicam uma fonte mantélica anomalamente enriquecida, o que é corroborado pelos valores de $\mathrm{T}_{\mathrm{DM}}$ entre $730 \mathrm{Ma}$ e $830 \mathrm{Ma}$, paradoxais com as idades de resfriamento do magma ao redor de $72-56 \mathrm{Ma}$.

Em adição, foram comparados os dados de isótopos das ilhas oceânicas de Santa Helena e Tristão da Cunha. Pode-se observar no diagrama da Figura 9 a similaridade das assinaturas isotópicas de $\mathrm{Sr}$ e $\mathrm{Nd}$ entre as rochas do
Morro de São João e Tristão da Cunha, diferentemente das assinaturas observadas nas Ilhas de Santa Helena.

Esses dados isotópicos de $\mathrm{Nd}$ e $\mathrm{Sr}$ permitem indicar que o manto sublitosférico responsável pela geração das rochas do Morro de São João, e provavelmente também dos outros corpos alcalinos que ocorrem no Estado de São Paulo e Rio de Janeiro, apresenta composição isotópica Nd e Sr correspondente à Ilha Oceânica de Tristão da Cunha. Estes resultados são coerentes com os dados reportados por Sichel et al. (1997), permitem concluir sobre a similaridade das assinaturas isotópicas das rochas alcalinas de Tanguá, Itatiaia, Rio Bonito, Morro de São João e Ilha de Cabo Frio com as rochas da Ilha Oceânica de Tristão da Cunha. Proposta equivalente foi apresentada por Hawkesworth et al. (1986), baseada, por sua vez, em dados geofísicos.

$\mathrm{Na}$ mesma direção de argumentação, Brotzu et al. (2007) sugerem que os dados isotópicos de $\mathrm{Sr}$ e Nd das rochas alcalinas do Morro de São João por eles reportados (razões ${ }^{87} \mathrm{Sr} /{ }^{86} \mathrm{Sr}$ entre 0,7048 e 0,7061 e ${ }^{143} \mathrm{Nd} /{ }^{144} \mathrm{Nd}$ entre 0,51231 e 0.51239 ) apresentam uma significativa diferença entre os dados de diques alcalinos de Arraial do Cabo. Estas diferenças são interpretadas como resultado da origem das rochas do Morro de São João a partir de uma fonte no limite entre manto litosférico e astenosférico. Em adição, os autores supracitados identificam uma clara diferença entre os dados isotópicos do Morro de São João (também lançados na Figura 9) e os dados de Trindade, descartada a hipótese de cogeneticidade entre estes dois complexos alcalinos, similarmente às conclusões do presente trabalho.

\section{AGRADECIMENTOS}

Os autores agradecem a FAPERJ (Processo 2005/ 00234) pelo custeio das atividades de campo e análises químicas. Os autores também agradecem a leitura crítica de dois revisores da revista que em muito contribuíram para a melhoria do presente trabalho. Aos colegas do Departamento de Recursos Minerais (RJ), UFRJ e UFRRJ pelas discussões e contribuições ao debate sobre o tema.

\section{REFERÊNCIAS BIBLIOGRÁFICAS}

ALMEIDA, F. The system of continental rifts bordering the Santos basin, Brazil. Anais da Academia Brasileira de Ciências, v. 48, p. 15-26, 1976.

ALMEIDA, F. Distribuição regional e relações tectônicas do magmatismo pós-paleozóico no Brasil. Revista Brasileira de Geociências, v. 16, p. 325-349, 1986.

ALVES, E. C., SICHEL, S. E. Compartimentação tectôni- 
ca da margem continental sudeste e área oceânica adjacente e suas implicações com o bordo continental. In: SIMPÓSIO DE GEOLOGIA DO SUDESTE, 5., 1997, Itatiaia. Atas... Itatiaia, 1997. p. 40-42.

AMARAL, G.; BUSHEE, J.; CORDANI, U.G.; KAWASHITA, K.; REYNOLDS, J. H. Potassium-argon ages of alkaline rocks from southern Brazil. Geochimica et Cosmochimica Acta, v. 31, p. 117-142, 1967.

BROTZU, P.; MELLUSO, L.; BENNIO, L.; GOMES, C. B.; LUSTRINO, M.; MORBIDELLI, L.; MORRA, V.; RUPERTI, E.; TASSINARI, C.; D' ANTONIO, M. Petrogenesis of the early cnozoic potassic alkaline complex of Morro de São João, southeastern Brazil. Journal of South America Earth Science, v. 24, p. 93-115, 2007.

CORDANI, U. G.; TEIXEIRA, W. Comentários sobre as determinações geocronológicas existentes para as regiões das folhas Rio de Janeiro, Vitória e Iguapé. Carta Geológica do Brasil ao Milionésimo, folhas Rio de Janeiro (SF.23), Vitória (SF.24) e Iguapé (SF.23). [Brasília]: MME/DNPM, 1979. p.175-207. (Apêndice 1).

DE PAOLO, D. J. (1988). Neodymiun Isotope Geochemistry. Mineral and Rocks, 20. New York: Springer-Verlag, 1988. $181 \mathrm{p}$.

DRM/RJ. Projeto carta geológica do Estado do Rio de Janeiro. Texto Explicativo das Folhas Morro de São João e Barra de São João. Rio de Janeiro: DRM, 1998. 64 p. (Texto inédito).

HAWKESWORTH, C. J.; MANTOVANI, M. S. M.; TAYLOR, P. N.; PALACZ, Z. Evidence from the Parana of south Brazil for continental contribution to DUPAL basalts. Nature, v. 322, p. 356-359, 1986.

HASUI, Y.; CARNEIRO, C. D. R.; COIMBRA, A. M. The Ribeira folded belt. Revista Brasileira de Geociências, v. 5, p. 257-266, 1975.

HEILBRON, M.; PEDROSA-SOARES, A. C.; CAMPOS NETO, M. C.; SILVA, L. C.; TROUW, R. A.; JANASI, V. A. Província Mantiqueira. In: MANTESSO-NETO, V.; BARTORELLI, A.; CARNEIRO, C. D. R.; BRITO-NEVES, B. B. Geologia do continente sul-americano: evolução da obra de Fernando Flávio Marques de Almeida. São Paulo: Beca, 2004. p. 203-234.

HELMBOLD, R. Resumo da geologia do Estado da Guanabara. [S.1.: s.n], 1967. p. 31-34. (Relatório da Comissão Especial do CNPq, 5).
HERTZ, N. Time of spreading in the south atlantic: information from Brazilian alkalic rocks. Geological Society of American Bullettin, n. 88, p. 101-112, 1977.

JOHANSSEN, A. A. A descriptive petrography of the igneous rocks. Chicago: University of Chicago Press, 1939. v. 1.

LAMEGO, A. R. Relatório anual do diretor, ano de 1956. Rio de Janeiro: DNOM/DGM, 1956. 137 p.

MARSH, I. S. Relationships between transform directions and alkaline igneous roks lineaments in Africa and South America. Earth Planet. Science Letters, v. 18, p. 317-323, 1973.

OLIVEIRA, A. O. Serviços de campo no Estado do Rio de Janeiro - Rel. Anual do Diretor. Rio de Janeiro: DGMDNPM, 1952.

OUREIRO, S. G.; CUPERTINO, J. A.; SZATMARI, P.; THOMAZ-FILHO, A. Estudo sobre o magmatismo no limite entre as bacias de Santos e Campos. In: SIMPÓSIO DE VULCANISMO E AMBIENTES ASSOCIADOS,3., 2005, Cabo Frio. Anais... Cabo Frio, 2005. p. 189-194.

RICCOMINI, C. O Rift continental do sudeste do Brasil. 1991. 256 f. Tese (Doutorado) - Instituto de Geociências, Universidade de São Paulo, São Paulo. 1991.

ROLLINSON, H. Using geochemical data: evaluation, presentation, interpretation. Harlow: Longman Scientific Technical, 1993. $352 \mathrm{p}$.

ROSIER, G. F. Pesquisas geológicas da parte oriental do Estado do Rio de Janeiro e na parte vizinha do Estado de Minas Gerais. Boletim do DNPM, v. 222, p. 1-40, 1965.

SCHMITT, R. S.; TROUW, R. A. J.; VAN SCHMUS, W. R.; PIMENTEL, M. M. Late amalgamation in the central part of west Gondwana: new geochronological data and the characterization of a cambrian collisional orogeny in the Ribeira Belt (SE Brazil). Precambrian Research, v. 133, n. 1-2, p.29-61, 2005.

SICHEL, S. E.; ALVES, E. C.; DIAS, M. S. Geocronologia dos maciços alcalinos de Itatiaia, Tanguá, Rio Bonito, Morro de São João e Ilha de Cabo Frio (RJ) e a natureza do lineamento alcalino de Cabo Frio. In: SIMPÓSIO DE GEOLOGIA DO SUDESTE, 5., 1997, Itatiaia. Atas... Cabo Frio, 1997. p. 62-64.

SONOKI, I. K.; GARDA, G. M. Idades K-Ar de rochas alcalinas do Brasil Meridional e Paraguai Oriental: compi- 
lação e adaptação as novas constantes de decaimento. Boletim IG-USP, Série Científica, v. 19, p. 63-85, 1988.

SФRENSEN, H. The alkaline rocks. London: John Wiley \& Sons, 1974. $622 \mathrm{p}$.

STRECKEISEN, A. L. Classification and nomenclature of igneous rocks. Neues Jahrbuch Mineralogie, Abhandlungen., v. 107, n. 2-3, p. 144-240, 1967.

SUN, S. S.; MCDONOUGHT, W. F. Chemical and isotope systematics of oceanic basalts: implications for mantle composition and process. In: MAGMATISM in the ocean basins. Geological Society, 1989. p. 313-345. (Special Publication, 42).

THOMAZ FILHO, A.; RODRIGUES, A. L. O alinhamento de rochas alcalinas Poços de Caldas - Cabo Frio (RJ) e sua continuidade na cadeia Vitória Trindade. Revista Brasileira de Geociências, n. 2, v. 29, p. 189-194, 1998.

THOMAZ FILHO, A.; CESERO, P.; MIZUSAKI, A. M.; LEÃO, J. G. Hot spot volcanic tracks and their implications for south american plate motion, Campos basin (Rio de Janeiro state), Brazil. Journal of South American Earth Sciences, v. 18, n. 3-4, p. 383-389, 2005.

THOMPSON, R. N.; GIBSON, S. A.; MITCHELL, J. G.; DICKIN, A. P.; LEONARDOS, O.H.; BROD, J.A.; GREENWOOD, J.C. Migrating cretaceous-eocene magmatism in the Serra do Mar Alkaline Province, SE Brazil: the dog-legged track of devious Trindade mantle plume. Journal of Petrology, v. 39, n. 8, p. 1493-1526, 1998.

VALENÇA, J. Rochas alcalinas do Estado do Rio de Janeiro. Revista de Mineração e Metalurgia, Ano 39, n. 366, p. 6-11, 1975.

ZINDLER, A.; HART, S. Chemichal Geodynamics. Annual Reviews of Earth Planetary Sciences, v. 14, p. 493-571, 1986. 